\title{
Overview of the Special Issue
}

\section{"Meteorological Disasters and Climate Variations in Historical Times"}

\author{
Takehiko MIKAMI*, Masumi ZAIKI**, \\ Junpei HIRANO* and Wataru MORISHIMA ${ }^{* * *}$
}

In early July of this year (2018), disasters occurred in Western Japan related to unprecedented mudslides and flooding rivers, which were caused by record-breaking heavy rainfalls that accompanied activated Baiu (early summer rain) fronts. The total number of fatalities exceeded 200. In July 2017 and in August 2014, similar torrential rainfall-related disasters also occurred in the same area, with 40 fatalities in Northern Kyushu and more than 70 in Hiroshima Prefecture.

Every time such severe meteorological disasters occur, expressions such as "unpredictable heavy rain", "unprecedented catastrophe", and "record-breaking heavy rain" are used. However, in Japan, official meteorological observational data were not available before 1872 in Hakodate and 1875 in Tokyo. Usually, early observational data before the 1870 s are not certified as official records by the Japan Meteorological Agency (JMA). Therefore, even if a disaster is described as occurring "for the first time in the history of observations" or as "recordbreaking", it is based on data covering only a period of 140 years at most.

In Japan, studies for reconstructing climate variations since the 17 th century, which include the Little Ice Age, have been undertaken by a few historical climate researchers, mainly based on historical diary weather records kept in local libraries (e.g., Mikami, 2008; Hirano and Mikami, 2008; Hirano et al., 2012, 2013; Mikami et al., 2015). This journal (Journal of Geography), also featured the special issue "Little Ice Age in Japan" (Vol. 102, No. 2, 1993), which documented attempts to reconstruct climate variations during the Little Ice Age from old weather diaries, tree ring data, and cherry blossom records. In recent years, in addition to qualitative data such as diaries, several examples of meteorological observational data before JMA official observations started have been found in Japan. Correction, homogenization, and digitization of these data are proceeding, and longer-term meteorological time-series combined with JMA's official data will become available. Such longer observational time-series in comparison with reconstructed climate timeseries will make it possible to quantitatively analyze climate variations, and objectively evaluate the intensities and tracks of tropical typhoons, which have caused heavy rainfall and strong winds since historical times.

The longest period covered by this special issue "Meteorological Disasters and Climate Variations in Historical Times" dates back nearly 300 years, and includes nearly 200 years since the 18th century when official meteorological observational data were not available in Japan. The target period includes the Little Ice Age during the Edo period of Japan, and it is possible to discuss meteorological disasters in

\footnotetext{
* Faculty of Liberal Arts, Teikyo University, Hachioji, 192-0395, Japan

** Faculty of Economics, Seikei University, Musashino, 180-8633, Japan

*** College of Humanities and Sciences, Nihon University, Tokyo, 156-8550, Japan
} 
relation to long-term climate change. One problem is to obtain a method for objectively and quantitatively evaluating actual climate variations and meteorological disasters in historical times without meteorological observational data.

In this special issue, the following research themes are discussed: (1) research on unofficial meteorological observation records before JMA observations started, (2) study on climate reconstruction based on diary weather records, (3) research on 19th century meteorological observations made by foreign missionaries, (4) research on typhoon track reconstructions using meteorological observation data from the 19th century, and (5) research on historical meteorological disasters based on documentary materials in Japan and China.

Therefore, the purpose of this special issue is to understand long-term climate variations spanning hundreds of years by clarifying the actual state of fluctuations in the intensity of various weather disasters, occurrence frequencies, typhoon tracks, and so on. This special issue is outlined below in order.

Zaiki et al. (2018) collected meteorological data from various parts of Japan, which were observed in the 19th century before the Japan Meteorological Agency was established. After correction and homogenization of these data, it is clear that the temperature variations in the South-eastern Kanto region from 1840 to 1850 are characterized by a climate with warm winters and summers. In addition, detailed meteorological data observed in the latter half of the nineteenth century (after 1877), which were obtained from coastal lighthouses in Japan, are also being digitized and are expected to be used effectively in climate change research.

Grossman et al. (2018) used the following materials for their analysis: (1) Englishlanguage newspaper published in Japan, (2) Historical Weather Database of Japan, (3) lighthouse meteorological observation records from various parts of Japan, (4) logbooks of UK/US ships, and (5) Imperial Meteorological Observation Data of Tokyo. As a result, in
1877, four typhoons were detected to have approached and landed on the Japanese coastal area, and attempts were made to reconstruct the central positions, moving tracks, lowest pressures, and damage. In this paper, the importance of clarifying the tracks and intensities of historical typhoons is pointed out.

Kubota (2018) compared two typhoons which landed on the Kii Peninsula of Japan and the Visayas area of the Philippines in 2011 and 2013, respectively, with typhoons occurring at the end of the 19th century, in terms of moving tracks/speed and disaster situations. During the 19th century, although digitized official meteorological observation data cannot be obtained, a large number of paper-based meteorological records are available in Japan and Southeast Asia, which would be very valuable for reconstructing past typhoons. "Data rescue" activities aimed at imaging and digitizing them should be encouraged.

Beillevaire (2018) analyzed and examined, from a meteorological historical point of view, the life and local meteorological observations of the French missionary Father Louis Furet, who was sent to the Ryukyu Kingdom (present Okinawa) in the latter half of the $1850 \mathrm{~s}$. The observational record of Furet is included in an official document of the "French National Weather Service", which contains detailed meteorological observational data obtained during his stay in Ryukyu. These data give important clues for understanding the climate of Southwest Japan in the mid-19th century.

Demarée et al. (2018) focused on the barometric observations conducted five times a day during the period $1856-1858$ by Father Furet mentioned above. Barometric air pressure data were corrected for sea level and temperature, and monthly mean values were calculated and graphed in comparison with present average values. Besides, daily variations in the atmospheric pressure data indicate that a remarkable pressure drop on May 18, 1857 might have been caused by an approaching typhoon witnessed by Father Furet.

Tagami et al. (2018) clarify strong wind- 
related disasters in East Asia and their variations during the Little Ice Age since 1700 by analyzing historical weather documents in Japan and China. The results indicate that strong wind-related disasters in Japan and China were mainly due to tropical cyclones and typhoons; therefore, they discuss the relationships between long-term fluctuations in the areas/times of occurrence and the east-west displacement of Pacific high pressure. Longterm historical documents, which include meteorological disasters occurring over hundreds of years, will play important roles in climate change research.

Hirano et al. (2018) analyzed the characteristics of rainfall fluctuations in Yokohama from 1863 to 1869, for which JMA observational data are not available, using meteorological records from observations carried out by J.C. Hepburn, an American missionary. As a result, it is revealed that the summer in 1868 was extremely rainy, whereas rainfall in 1867 was extremely small with a tendency for dry weather. Comparisons with the meteorological disaster record are in good agreement for both years.

Ichino et al. (2018) focused on the close relationship between daily weather conditions and global solar radiation, and attempted to estimate monthly mean solar radiation based on weather records described in diaries kept in various parts of Japan during the first half of the 19th century. Severe famines occurred during the target period in the 1830s. In 1836, serious crop damage was caused by cold weather, and solar radiation estimated from diary weather records decreased from May to September in many places.

Tanioka (2018) analyzes the chronology InpuNenpyo (1697-1870), which includes meteorological disaster records for events such as "heavy rain", "flood", "heavy snow", and "drought" in Tottori Prefecture, western Japan, and clarifies long-term changes in the frequency of related disasters.

Fukuma (2018) collected daily weather and related phenomena from an Edo period (16611868) diary kept in the Hirosaki City Library, and digitized all the data to create Excel files. By analyzing the digitized diary weather descriptions, long-term fluctuations in the frequency of meteorological disasters can be clarified by searching for specific terms such as floods and mudslides.

Finally, we hope this special issue will contribute to the progress of climate change studies and will be used for predicting future meteorological disasters .

\section{References}

Beillevaire, P. (2018): Father Louis Furet, Missionary of the Paris Foreign Missions Society: His life and scientific observations on Okinawa (1855-1862). Journal of Geography (Chigaku Zasshi), 127, 483501.

Demarée, G.R., Mailier, P., Beillevaire, P., Mikami, T., Zaiki, M., Tsukahara, T., Tagami, Y. and Hirano, J. (2018): The atmospheric pressure observations 1856-1858 by Father Louis Furet, at Naha, Japan. Journal of Geography (Chigaku Zasshi), 127, 503511.

Fukuma, Y. (2018): Making the database of Hirosaki Clan Agency Diary and its significance. Journal of Geography (Chigaku Zasshi), 127, 565-568. (in Japanese with English abstract)

Grossman, M.J., Zaiki, M., Mikami, T. and Mock, C. (2018): Reconstructing typhoons affecting Japan in 1877. Journal of Geography (Chigaku Zasshi), 127, 457-470.

Hirano, J. and Mikami, T. (2008): Reconstruction of winter climate variations during the 19th century in Japan. International Journal of Climatology, 28, 1423-1434.

Hirano, J., Ohba, T., Morishima, W. and Mikami, T. (2012): Reconstruction of winter temperature since the 1830s in Kawanishi based on historical weather documents. Geographical Review of Japan (Series A), 85, 275-286. (in Japanese with English abstract)

Hirano, J., Ohba, T. Morishima, W., Zaiki, M. and Mikami, T. (2013): Reconstruction of July temperature variations since the 1830 s in Kawanishi based on historical weather documents. Geographical Review of Japan (Series A), 86, 451-464. (in Japanese with English abstract)

Hirano, J., Mikami, T., Zaiki, M. and Nishina, J. (2018): Analysis of precipitation data at Yokohama, Japan, from 1863 to 1869 observed by J.C. Hepburn. Journal of Geography (Chigaku Zasshi), 127, 531541.

Ichino, M., Mikami, T. and Masuda, K. (2018): Fluctuations of global solar radiation in Japan during the first half of the 19th century as estimated from 
historical weather records. Journal of Geography (Chigaku Zasshi), 127, 543-552. (in Japanese with English abstract)

Kubota, H. (2018): Comparison of tropical cyclones Haiyan and Talas with tropical cyclones having similar tracks in the past 120 years. Journal of Geography (Chigaku Zasshi), 127, 471-482.

Mikami, T. (2008): Climatic variation in Japan reconstructed from historical documents. Weather (U.K.), 63, 190-193.

Mikami, T., Zaiki, M. and Hirano, J. (2015): A history of climatic change in Japan in Environment and Society in the Japanese Island edited by Batten, B.L. and Brown, P.C., Oregon State University Press, 197-212.

Tagami, Y., Demarée, G.R., Mailier, P., Beillevaire, P., Mikami, T., Zaiki, M., Tsukahara, T. and Hirano, J.
(2018): Strong wind hazards and their variations in East Asia during the Little Ice Age. Journal of Geography (Chigaku Zasshi), 127, 513-529. (in Japanese with English abstract)

Tanioka, T. (2018): A study of weather records in Inpu-Nenpyo, an official historical document from Tottori, northwest coast of Japan. Journal of Geography (Chigaku Zasshi), 127, 553-564. (in Japanese with English abstract)

Zaiki, M., Mikami, T., Hirano, J., Grossman, M.J., Kubota, H. and Tsukahara, T. (21018): Climate characteristics in the south-eastern Kanto region of Japan derived from mid to late 19th century meteorological records. Journal of Geography (Chigaku Zasshi), 127, 447-455. (in Japanese with English abstract) 